\title{
Covid-19 Pandemic: An Overview
}

Öz

Aralık 2019 tarihinde Çin'de başlayan "ağır akut solunum sendromu koronavirüs 2"nin ("Severe acute respiratory syndrome coronavirus 2", SARS-CoV-2) neden olduğu koronavirüs hastalığı 2019 ("Coronavirus disease 2019", COVID-19) salgını, kısa sürede tüm dünyaya yayılmıs ve Mart 2020'de Dünya Sağlık Örgütü tarafından pandemi ilan edilmiştir. Şimdiye kadar, tüm dünyada üç milyondan fazla insan etkilenmiş ve iki yüz binden fazla kişi hayatını kaybetmiştir. Bu derlemede COVID-19 ve SARS-CoV-2 hakkındaki mevcut bilgiler özetlenmiștir.

Anahtar kelimeler: COVID-19, koronavirüs, pandemi, SARS-CoV-2

\section{ABSTRACT}

In December 2019, coronavirus disease 2019 (COVID-19) outbreak, caused by Severe acute respiratory syndrome coronavirus 2 (SARS-CoV-2) in China, has spread globally in a short time and World Health Organization declared the outbreak as a pandemic in March 2020. Until now, more than three million people have been infected, and more than two hundred thousand have died. In this review, the current knowledge about COVID-19 and SARS-CoV-2 was summarized.
Geliş/Received: 02 Mayıs/May 2020 Kabul/Accepted: 04 Mayıs/May 2020 Basım/Published: 30 Nisan/April 2020

Atıf/Cite as: Polat C. Covid-19 pandemisi: Genel bir bakıs. ANKEM Derg. 2020;34(1):25-31.

Ceylan Polat

Hacettepe Üniversitesi Tıp Fakültesi Tıbbi Mikrobiyoloji Anabilim Dalı Ankara - Türkiye

- ceylan.polat@hacettepe.edu.tr ORCID: 0000-0003-1511-4177

Keywords: Coronavirus, COVID-19, pandemics, SARS-CoV-2

\section{GiRiş}

Aralık 2019'da Çin'in Wuhan şehrinden etiyolojisi belli olmayan pnömoni vakaları bildirilmiştir(44). Kısa sürede salgın büyümüş ve vaka sayısı yaklaşık 85.000 'e ulaşmıştır. Yapılan analizler sonucunda, etkenin yeni bir koronavirüs olduğu anlaşılmış ve 2019-nCoV ("novel coronavirus") olarak adlandırılmıştır ${ }^{(49)}$. Salgın, 11 Mart 2020 tarihinde Dünya Sağlık Örgütü (DSÖ) tarafından pandemi olarak ilan edilmiş ve bu yeni virüs, Uluslararası Virüs Taksonomisi Komitesi ("International Committee on Taxonomy of Viruses", ICTV) tarafından ağır akut solunum sendromu koronavirüs 2 ("Severe acute respiratory syndrome coronavirus 2", SARS-CoV-2) olarak adlandırılmıştır ${ }^{(17,42)}$. Aynı tarihte, Türkiye'den ilk vaka bildirimi yapılmıştır ${ }^{(14)}$. DSÖ’nün verilerine göre şimdiye kadar 213 ülkeden bildirim yapılmış ve 3,000,000'un üzerinde vaka doğrulanmıştır ${ }^{(11)}$.
Damlacık yoluyla bulaşan ve hastalarda en sık ateş, kuru öksürük ve nefes darlığı gibi semptomlarla kendini gösteren koronavirüs hastalığı 2019'un (“Coronavirus disease 2019", COVID-19) tedavisinde kullanılabilecek, doğrudan etkili bir ilaç veya aşı henüz bulunmamaktadır. Bu nedenle enfeksiyon etkeninden korunma önem taşımaktadır.

Bu derlemede, SARS-CoV-2'nin yapısı, bulaş yolları, epidemiyolojisi, kliniği, tanısı, tedavisi ve enfeksiyondan korunma hakkındaki güncel bilgiler özetlenmiştir.

\section{GENOM YAPISI}

Coronaviridae ailesinin üyeleri, zarflı, pozitif polariteli, tek iplikli RNA genomuna sahiptir. SARSCoV-2, bu ailenin Betacoronavirus cinsine aittir ${ }^{(17)}$. Yaklaşık 30,000 nükleotid içeren viral genomu, yapısal ve yapısal olmayan proteinleri kodlayan açık okuma 


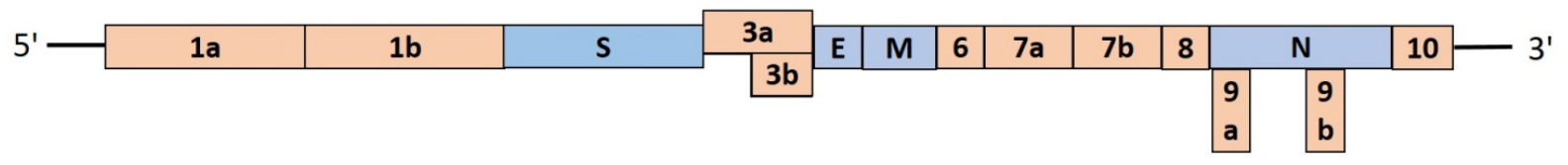

\section{0 kilobaz}

Şekil 1. SARS-CoV-2 genomu (21 numaralı kaynaktan uyarlanmıştır). 1a, 1b, 3a, 6, 7a, 7b, 8 ve 10, ORF bölgelerini ifade etmektedir. S, E, $\mathrm{M}$ ve $\mathbf{N}$ yapısal proteinlerdir.

bölgelerinden ("open reading frame", ORF) oluşmaktadır(Şekil1). Nükleokapsid(N), transmembran (M), diken ("spike", S) ve zarf ("envelope", E) olmak üzere dört yapısal protein kodlanmaktadır.

Virüsün kökeni henüz kesin olarak bilinmemektedir. Filogenetik analizler, SARS-CoV ile $\% 79$ ve MERS-CoV ile \% 50 benzerliğe sahip olan SARSCoV-2'nin genetik olarak yarasa kökenli SARS benzeri koronavirüslere daha yakın (nükleotid düzeyinde $\% 88$ benzerlik) olduğunu göstermektedir ${ }^{(8,27)}$. Şimdiye kadar bildirilmiş olan SARSCoV-2 dizileri incelendiğinde, virüsün yarasalardan insanlara geçişinin, 2019 yılının Kasım ayı sonunda ya da Aralık ayı başında gerçekleşmiş olabileceğ düşünülmüştür $r^{(3)}$.

SARS-CoV-2 ait 160 tüm genomun filogenetik ağ analizinin yapıldığı bir çalışmada; $A, B$ ve $C$ olmak üzere üç farklı varyant saptandığı, $A$ ve $C$ tiplerinin Avrupa ve Amerika'da görüldüğü, B tipinin ise Doğu Asya'da bulunduğu bildirilmiştir ${ }^{(16)}$. SARS-CoV-2'nin 103 tüm genomunun popülasyon genetik analizlerinin yapıldığı bir başka çalışmada ise, virüsün belirli bölgede izlenen aminoasit türüne göre $L$ ve $S$ olmak üzere iki ana tipe ayrıldığı ve $L$ tipinin $S$ tipine göre daha yaygın olduğu görülmüştür ${ }^{(36)}$.

COVID-19 hastalarından izole edilen SARSCoV-2 dizileri incelendiğinde, dizilerin birbirleri ile yüksek oranda benzerlik (\% 99,98) gösterdiği saptanmış ve bu durum pandemi sırasında henüz çok fazla varyasyonun ortaya çıkmadığı şeklinde yorumlanmıştır ${ }^{(21,27,48)}$.

\section{EPIDEMIYOLOJi}

ilk COVID-19 vakası, bir haftadır süren ateş, göğüs sıkışması, öksürük, halsizlik ve ağrı şikayetiyle 26 Aralık 2019 tarihinde Çin'in Hubei eyaletindeki Wuhan şehrinde sağlık kuruluşuna başvurmuştur ${ }^{(44)}$. Çin'de bulunan DSÖ Ofisi, 31 Aralık 2019 tarihinde Wuhan şehrinde saptanan etiyolojisi bilinmeyen pnömoni vakaları hakkında bilgilendirilmiştir(31). Wuhan'daki 44 vaka, 3 Ocak 2020 tarihinde DSÖ’ye bildirilmiştir. SARS-CoV-2'ye ait genetik dizi, Çin tarafından 12 Ocak 2020 tarihinde açıklanmıştır ${ }^{(43)}$. Aynı gün salgının, Wuhan şehrindeki Huanan deniz ürünleri pazarı ile ilişkili olduğu bildirilmiştir. $\mathrm{Bu}$ pazarda deniz ürünlerinin yanı sıra canlı yabani hayvanlar da satılmaktadır. Wuhan şehrine giriş çıkışlar, 23 Ocak 2020 tarihinde yasaklanmış ve şehir içindeki hareketlilik kısıtlanmıştır ${ }^{(15)}$. Avrupa'daki ilk vaka, 24 Ocak 2020 tarihinde Fransa'dan bildirilmiştir. Salgın, DSÖ tarafından 30 Ocak 2020 tarihinde endişe uyandıran uluslararası halk sağlığı tehdidi, 11 Mart 2020 tarihinde de pandemi olarak ilan edilmiştir ${ }^{(35,42)}$. Türkiye'de ilk vaka ise 11 Mart 2020 tarihinde saptanmıştır(14) (Şekil 2).

DSÖ’nün verilerine göre 29 Nisan 2020 tarihi itibarı ile 213 ülkeden 208,112 ölüm, 3,024,059 doğrulanmış vaka bildirilmiştir ${ }^{(11)}$. Türkiye'den ise 29 Nisan 2020 tarihi itibarı ile 3,081'i vefat ile sonuçlanmış 117,589 vaka bulunmaktadır(47).

\section{BULAŞ}

SARS-CoV-2, solunum damlacıkları ve temas yoluyla bulaşmaktadır(24,26). Enfekte kişilerin 


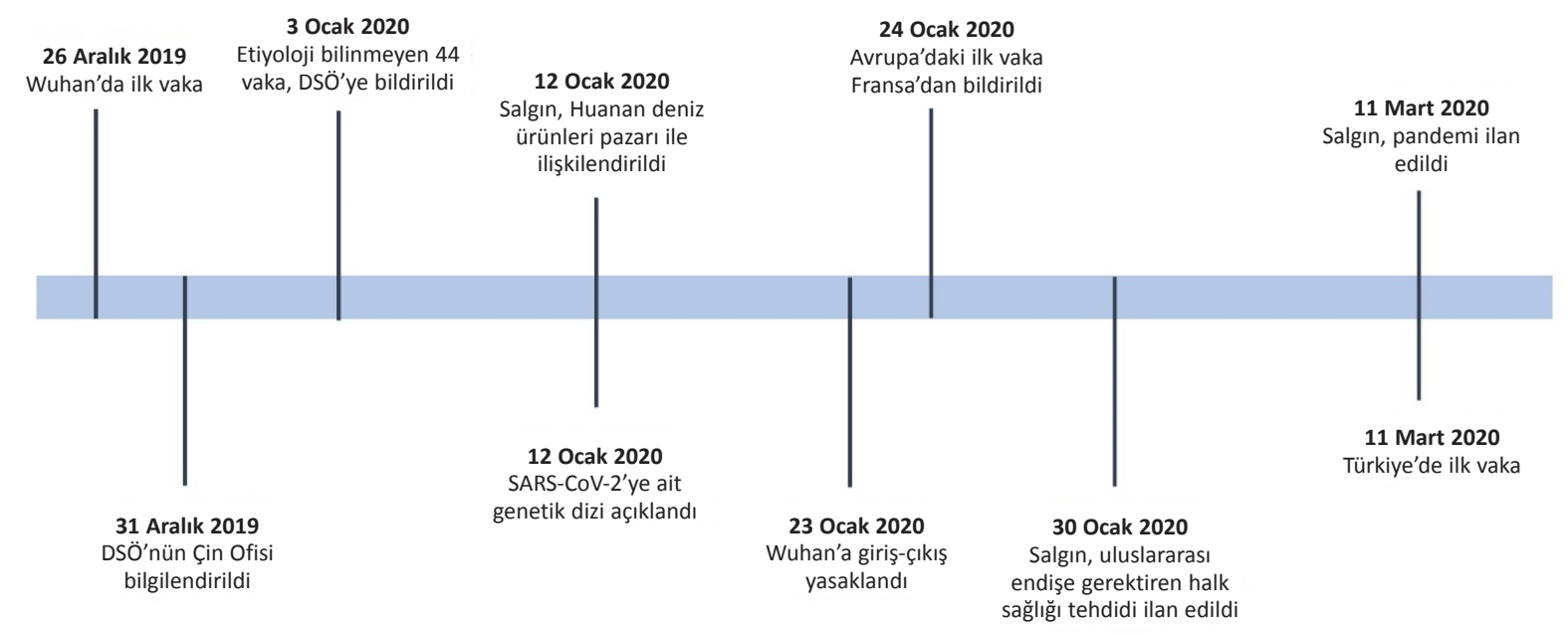

Şekil 2. COVID-19 pandemisindeki önemli gelişmelerin kronolojik sıralaması.

öksürmesi ya da hapşırması ile saçılan solunum yolu kaynaklı damlacıklara, mukoza ve konjonktiva yoluyla maruz kalan kişiler risk altındadır ${ }^{(28)}$. Enfekte kişilerle doğrudan temasın yanı sıra enfekte kişilerin çevresindeki yüzeylerle ve nesnelerle dolaylı temas da bulaşa neden olmaktadır ${ }^{(29)}$. Virüs, asemptomatik kişilere ait örneklerde de saptanabildiğinden, bu kişilerin de bulaştırıcı olabilecekleri unutulmamalıdır. $\mathrm{Bu}$ nedenle, el hijyeni, çevre temizliği ve dezenfeksiyonuna dikkat edilmesi, sosyal mesafenin korunması (en az 1 metre), ateş veya solunum semptomları olan kişilerle yakın ve korunmasız temastan kaçınııması önem taşımaktadır ${ }^{(28)}$.

\section{KLiNiK}

SARS-CoV-2'nin yol açtığı hastalık, DSÖ tarafından COVID-19 olarak tanımlanmıştır ${ }^{(17)}$. Hastalarda en sık görülen semptomlar, ateş, kuru öksürük ve nefes darlığıdır ${ }^{(40)}$. Bunların yanı sıra titreme, kas ağrısı, baş ağrısı, boğaz ağrısı, tat ve koku alma duyusunda kayıp da görülebilmektedir. Ağır vakalarda, pnömoni ve ağır akut solunum yolu enfeksiyonu gelişebilmektedir ${ }^{(18)}$. Ileri yaşta $(\geq 80)$ olan kişiler ile hipertansiyon, diyabet, kardiyovasküler hastalık, kanser ve kronik akciğer hastalıkları gibi sistemik hastalığı olan kişilerde fatalite oranı daha yüksektir ${ }^{(45)}$.
İnkübasyon süresi, ortalama 5-6 gün (2-14 gün) olarak bildirilmiştir ${ }^{(2,18,23-25)}$. Ancak bazı vakalarda bu süre daha uzun olabilmektedir.

\section{TANI}

Şüpheli vakaların doğrulanmasında, gerçekzamanlı ters transkripsiyon polimeraz zincir reaksiyonu ("real-time reverse transcription polymerase chain reaction", rRT-PCR) gibi nükleik asit amplifikasyonunu sağlayan testler kullanılmakta ve viral RNA'nın saptanması hedeflenmektedir.

Önceden bildirilmiş olan SARS-CoV ve yarasayla ilişkili koronavirüslerin genom dizileri ile salgın sırasında bildirilen ve SARS-CoV-2'ye ait beş genom dizisi kullanılarak üç farklı rRT-PCR protokolü oluşturulmuştur ${ }^{(10)}$. Bu protokollerde, virüsün zarf proteinini kodlayan E geni, RNA bağımlı RNA polimerazı ("RNA-dependent RNA polymerase", RdRp) kodlayan RdRp geni ve nükleokapsidi kodlayan $\mathrm{N}$ geni hedeflenmiştir. Virüsün RdRp/Hel geninin farklı bir bölgesini hedefleyen bir başka rRT-PCR protokolü de geliştirilmiştir( ${ }^{(6)}$.

Enfekte kişilerde rRT-PCR testlerinde negatif sonuçlar alınmasında çeşitli faktörlerin rol oynayabileceği unutulmamalıdır. Bu faktörlerden 
bazıları, örnek kalitesi, örneğin enfeksiyonun hangi döneminde alındığı, uygun şekilde işlenip işlenmediği, laboratuvara ulaştırılması sürecindeki koşullar ve testle ilişkili teknik nedenlerdir (PCR inhibisyonu, mutasyon) ${ }^{(22)}$

Serolojik testler, nükleik asit amplifikasyon testlerinin negatif sonuç verdiği ve COVID-19 enfeksiyonu ile epidemiyolojik ilişkisi olan geç dönem vakalarda tanıyı desteklemek amacıyla kullanılabilmektedir (28,29). Serolojik testlerin uygulanması, temaslı kişilerin izlemi, bölgesel serolojik sürveyans ve hastalığı geçirmiş kişilerin saptanması açısından önem taşımaktadır ${ }^{(30)}$.

Şüpheli ve doğrulanmış vakalarda tanıyı desteklemek ve enfeksiyonun akciğerdeki yaygınlığını belirlemek amacıyla toraks bilgisayarlı tomografisi (BT) kullanılmaktadır. COVID-19 pnömonisi gelişen hastalarda, bilateral, periferik yerleşimli, buzlu cam opasiteleri görülen toraks BT bulgusu karakteristiktir ${ }^{(7,19,34,45)}$.

\section{TEDAVI VE KORUNMA}

SARS-CoV-2'ye doğrudan etkili, spesifik bir tedavi bulunmamaktadır. Virüse karşı etkin ve güvenilir bir tedavi geliştirilebilmesi için çok sayıda çalışma halen devam etmektedir ${ }^{(38)}$.

DSÖ önerileri doğrultusunda, Dünya'da ve Türkiye'de en sık kullanılan ajanlar, hidroksiklorokin/ klorokin, remdesivir, favipiravir ve lopinavir/ ritonavirdir ${ }^{(13,32,46)}$. Son zamanlarda yapılan çalışmalar ile, nitazoksanit ve ivermektinin de SARS-CoV-2'ye karşı in vitro etkinlikleri bildirilmiştir ${ }^{(4,41)}$. Ancak, bu konuda in vitro, in vivo ve klinik çalışmalarla desteklenecek daha fazla veriye intiyaç vardır.

Komorbiditeleri önlemek amacıyla COVID-19 hastalarına destek tedavisi uygulanmaktadır(9). Bu bağlamda hastalara, mekanik ventilatör desteği ve oksijen saturasyonu \% 94'ten az ise ek oksijen desteği sağlanmakta, ikincil enfeksiyonları önlemek için antimikrobiyal tedaviler uygulanmaktadır.

Amerikan Gıda ve Ilaç Dairesi'nin ("U.S. Food and Drug Administration", FDA) 24 Mart 2020 tarihinde yayınladığı bir tavsiye kararı ile önceki yillarda H1N1 Influenza, SARS-CoV-1 ve MERS-CoV salgınlarında kullanılan immün plazma tedavisinin COVID-19'a karşı da etkili olmasının mümkün olduğu belirtilmiştir ${ }^{(12,19)}$. Yapılan çalışmalar, immün plazma tedavisi uygulanan hastaların yarar gördüğünü bildirmektedir ${ }^{(5,33)}$. Türkiye'de uygun endikasyonlarda hastalara immün plazma tedavisi uygulanmaktadır ${ }^{(12)}$.

SARS-CoV-2'ye yönelik aşı geliştirme çalışmaları devam etmektedir. Bu çalışmalarda nükleik asit (DNA ve RNA), virüs benzeri partikül, peptit, viral vektör, rekombinant protein, canlı zayıflatılmış virüs ve inaktive virüs gibi farklı birçok yaklaşımın benimsenmesi dikkat çekmektedir ${ }^{(37)}$. Bu çalışmalardan yaklaşık 20 tanesinde klinik öncesi çalışmalar yürütülürken, beş tanesinde faz I çalışmalara başlanmıştır.

Aşı çalışmalarında genellikle, nötralizan antikor indükleyicisi olması nedeniyle $S$ proteini hedef alınmaktadır(20,37). SARS-CoV-2'nin, konak hücreye girebilmek için, $\mathrm{S}$ proteini aracılı̆̆ıyla konak hücre yüzeyindeki anjiyotensin-dönüştürücü enzim 2 ("angiotensin-converting enzyme 2", ACE2) reseptörüne bağlandığı saptanmıştır ${ }^{(48)}$. ACE2 reseptörünün SARS-CoV tarafından da kullanılıyor olması, çapraz koruyuculuk sağlayacak bir aşının geliştirilmesi fikrini akıllara getirmektedir. Ancak SARS-CoV ve SARS-CoV-2'nin S proteinlerinin reseptör bağlanma bölgelerin-deki aminoasit dizilimlerinin oldukça değişken ve birbirlerinden farklı olması, bu durumu tartışmalı hale getirmektedir ${ }^{(1,39)}$.

\section{SONUÇ VE ÖNERILER}

Bu derlemede, dünya çapında bir halk sağlığı sorunu haline gelen COVID-19 pandemisi ve SARS- 
CoV-2 hakkındaki güncel bilgiler özetlenmiştir. Yapılacak çalışmalar sonucunda elde edilecek yeni veriler, virüsün yapısının ve kökeninin daha iyi anlaşılmasının yanı sıra SARS-CoV-2'ye karşı aşı ve antiviral tedavinin geliştirilmesi için gerekli bilgi birikimine de katkı sunacaktır. Yaşanan bu pandemiden çıkarılacak ulusal ve uluslararası düzeydeki dersler, ilerleyen yıllarda karşılaşılabilecek potansiyel salgınlara karşı daha hazırlıklı olabilmemize olanak sağlayacaktır.

Çıkar Çatışması: Yazar tarafından herhangi bir çıkar çatışması bildirilmemiştir.

Conflict of Interest: No conflict of interest was reported by the author.

\section{KAYNAKLAR}

1. Andersen KG, Rambaut A, Lipkin WI, Holmes EC, Garry RF. The proximal origin of SARSCoV-2. Nat Med. 2020;26:450-5. https://doi.org/10.1038/s41591-020-0820-9

2. Backer JA, Klinkenberg D, Wallinga J. Incubation period of 2019 novel coronavirus (2019- nCoV) infections among travellers from Wuhan, China, 20-28 January 2020. Euro Surveill. 2020;25(5). https://doi.org/10.2807/1560-7917. ES.2020.25.5.2000062

3. Benvenuto D, Giovanetti M, Salemi M, et al. The global spread of 2019-nCoV: a molecular evolutionary analysis. Pathog Glob Health. 2020;114(2):64-7.

https://doi.org/10.1080/20477724.2020.1725 339

4. Caly L, Druce JD, Catton MG, Jans DA, Wagstaff KM. The FDA-approved drug ivermectin inhibits the replication of SARS-CoV-2 in vitro. Antiviral Res. 2020;178:104787. https://doi.org/10.1016/j.antiviral.2020.104787

5. Casadevall A, Pirofski LA. The convalescent sera option for containing COVID-19. J Clin Invest. 2020;130(4):1545-8. https://doi.org/10.1172/JCI138003

6. Chan JF, Yip CC, To KK, et al. Improved molecular diagnosis of COVID-19 by the novel, highly sensitive and specific COVID-19-RdRp/Hel realtime reverse transcription-polymerase chain reaction assay validated in vitro and with clinical specimens. J Clin Microbiol. 2020;58(5):e0031020.

https://doi.org/10.1128/JCM.00310-20

7. Chen $\mathrm{N}$, Zhou M, Dong $\mathrm{X}$, et al. Epidemiological and clinical characteristics of 99 cases of 2019 novel coronavirus pneumonia in Wuhan, China: a descriptive study. Lancet. 2020;395(10223): 507-13. https://doi.org/10.1016/S0140-6736(20)30211-7

8. Ciotti M, Angeletti S, Minieri M, et al. COVID-19 outbreak: an overview. Chemotherapy. 2020;7:1-9. https://doi.org/10.1159/000507423

9. Clinical management of severe acute respiratory infection when COVID-19 disease is suspected, World Health Organization (WHO), https://www. who.int/publications-detail/clinicalmanagement-of-severe-acute-respiratoryinfection-when-novel-coronavirus-(ncov)infection-is-suspected, (erişim tarihi: 01.05.2020)

10. Corman VM, Landt O, Kaiser M, et al. Detection of 2019 novel coronavirus (2019-nCoV) by realtime RT-PCR. Euro Surveill. 2020;25(3). https://doi.org/10.2807/1560-7917. ES.2020.25.3.2000045

11. Coronavirus (COVID-19), World Health Organization (WHO), https://covid19.who.int/, (erişim tarihi: 30.04.2020)

12. COVID-19 İmmün (Konvalesan) Plazma Tedarik ve Klinik Kullanım Rehberi, T.C. Sağıı Bakanlığı Sağlık Hizmetleri Genel Müdürlüğü Kan ve Kan Ürünleri Dairesi Başkanlığı, https://covid19bilgi. saglik.gov.tr/depo/enfeksiyon-kontorlonlemleri/COVID19-PlazmaUygulamaRehberi. pdf, (erişim tarihi: 01.05.2020).

13. COVID-19 (SARS-CoV-2 enfeksiyonu) Rehberi Bilim Kurulu Çalışması, T.C. Sağıık Bakanlığı Halk Sağlığı Genel Müdürlüğü, https://covid19bilgi. saglik.gov.tr/depo/rehberler/COVID-19_ Rehberi.pdf, (erişim tarihi: 26.04.2020)

14. Demirbilek Y, Pehlivantürk G, Özgüler ZÖ, Alp ME. COVID-19 outbreak control, example of the ministry of health of Turkey. Turk J Med Sci. 
2020;50(SI-1):489-94.

https://doi.org/10.3906/sag-2004-187

15. Du Z, Wang L, Cauchemez S, et al. Risk for transportation of 2019 novel Coronavirus disease from Wuhan to other cities in China. Emerg Infect Dis. 2020;26(5):1049-52. https://doi.org/10.3201/eid2605.200146

16. Forster $P$, Forster $L$, Renfrew $C$, Forster $M$. Phylogenetic network analysis of SARS-CoV-2 genomes. Proc Natl Acad Sci USA. 2020;117(17):9241-3. https://doi.org/10.1073/pnas.2004999117

17. Gorbalenya AE, Baker SC, Baric RS, et al. The species severe acute respiratory syndromerelated coronavirus: classifying 2019-nCoV and naming it SARS-CoV-2. Nat Microbiol. 2020;5(4):536-44.

https://doi.org/10.1038/s41564-020-0695-z

18. Huang $C$, Wang Y, Li X, et al. Clinical features of patients infected with 2019 novel coronavirus in Wuhan, China. Lancet. 2020;395(10223):497506.

https://doi.org/10.1016/S0140-6736(20)30183-5

19. Interim Clinical Guidance for Management of Patients with Confirmed Coronavirus Disease (COVID-19), Centers for Disease Control and Prevention (CDC), https://www.cdc.gov/ coronavirus/2019-ncov/hcp/clinical-guidancemanagement-patients.html\#lab-findings, (erişim tarihi: 01.05.2020)

20. Jiang $S$, He $Y$, Liu S. SARS vaccine development. Emerg Infect Dis. 2005;11(7):1016-20. https://doi.org/10.3201/1107.050219

21. Jin Y, Yang H, Ji W, et al. Virology, epidemiology, pathogenesis, and control of COVID-19. Viruses. 2020;12(4). pii: E372.

https://doi.org/10.3390/v12040372

22. Laboratory testing for coronavirus disease 2019 (COVID-19) in suspected human cases: interim guidance, 2 March 2020, World Health Organization (WHO), https://www.who.int/ publications-detail/laboratory-testing-for2019-novel-coronavirus-in-suspected-humancases-20200117, (erişim tarihi: 28.04.2020)

23. Lauer SA, Grantz KH, Bi Q, et al. The incubation period of Coronavirus Disease 2019 (COVID-19) from publicly reported confirmed cases: estimation and application. Ann Intern Med. 2020.

https://doi.org/10.7326/M20-0504

24. Li Q, Guan X, Wu P, et al. Early transmission dynamics in Wuhan, China, of novel coronavirusinfected pneumonia. N Engl J Med. 2020;382(13):1199-207. https://doi.org/10.1056/NEJMoa2001316

25. Linton NM, Kobayashi T, Yang $\mathrm{Y}$, et al. Incubation period and other epidemiological characteristics of 2019 novel Coronavirus infections with right truncation: a statistical analysis of publicly available case data. J Clin Med. 2020;9(2). pii: E538.

https://doi.org/10.3390/jcm9020538

26. Liu J, Liao X, Qian S, et al. Community transmission of severe acute respiratory syndrome coronavirus 2, Shenzhen, China, 2020. Emerg Infect Dis. 2020;26(6). https://doi.org/10.3201/eid2606.200239

27. Lu R, Zhao X, Li J, et al. Genomic characterisation and epidemiology of 2019 novel coronavirus: implications for virus origins and receptor binding. Lancet. 2020;395(10224):565-74. https://doi.org/10.1016/S0140-6736(20)30251-8

28. Modes of transmission of virus causing COVID19: implications for IPC precaution recommendations, World Health Organization (WHO), https://www.who.int/publicationsdetail/modes-of-transmission-of-virus-causingcovid-19-implications-for-ipc-precautionrecommendations, (erişim tarihi: 28.04.2020)

29. Ong SWX, Tan YK, Chia PY, et al. Air, surface environmental, and personal protective equipment contamination by severe acute respiratory syndrome coronavirus 2 (SARSCoV-2) from a symptomatic patient. JAMA. 2020;323(16):1610-2. https://doi.org/10.1001/jama.2020.3227

30. Patel R, Babady E, Theel ES, et al. Report from the American Society for Microbiology COVID19 International Summit, 23 March 2020: value of diagnostic testing for SARS-CoV-2/COVID-19. mBio. 2020;11(2). pii: e00722-20. https://doi.org/10.1128/mBio.00722-20

31. Pneumonia of unknown cause - China, World Health Organization (WHO), https://www.who. 
int/csr/don/05-january-2020-pneumonia-ofunkown-cause-china/en/, (erişim tarihi: 27.04.2020)

32. Report of the WHO-China Joint Mission on Coronavirus Disease 2019 (COVID-19), World Health Organization (WHO), https://www.who. int/docs/default-source/coronaviruse/whochina-joint-mission-on-covid-19-final-report. pdf, (erişim tarihi: 01.05.2020)

33. Shen C, Wang Z, Zhao F, et al. Treatment of 5 critically ill patients with COVID-19 with convalescent plasma. JAMA. 2020;323(16): 1582-9.

https://doi.org/10.1001/jama.2020.4783

34. Shi $\mathrm{H}, \operatorname{Han} \mathrm{X}$, Jiang $\mathrm{N}$, et al. Radiological findings from 81 patients with COVID-19 pneumonia in Wuhan, China: a descriptive study. Lancet Infect Dis. 2020;20(4):425-34. https://doi.org/10.1016/S1473-3099(20)30086-4

35. Statement on the meeting of the International Health Regulations (2005) Emergency Committee regarding the outbreak of novel coronavirus (2019-nCoV), World Health Organization (WHO), https://www.who.int/ news-room/detail/23-01-2020-statement-onthe-meeting-of-the-international-healthregulations-(2005)-emergency-committeeregarding-the-outbreak-of-novel-coronavirus(2019-ncov), (erişim tarihi: 27.04.2020)

36. Tang $\mathrm{X}, \mathrm{Wu} \mathrm{C}$, Li $\mathrm{X}$, et al. On the origin and continuing evolution of SARS-CoV-2. Natl Sci Rev. 2020.

https://doi.org/10.1093/nsr/nwaa036

37. Thanh Le T, Andreadakis Z, Kumar A, et al. The COVID-19 vaccine development landscape. Nat Rev Drug Discov. 2020.

https://doi.org/10.1038/d41573-020-00073-5

38. Tu YF, Chien CS, Yarmishyn AA, et al. A review of SARS-CoV-2 and the ongoing clinical trials. Int J Mol Sci. 2020;21(7). pii: E2657. https://doi.org/10.3390/ijms21072657

39. Wan Y, Shang J, Graham R, Baric RS, Li F. Receptor recognition by the novel coronavirus from Wuhan: an analysis based on decade-long structural studies of SARS Coronavirus. J Virol. 2020;94(7). pii: e00127-20.

https://doi.org/10.1128/JVI.00127-20
40. Wang D, Hu B, Hu C, et al. Clinical characteristics of 138 hospitalized patients with 2019 Novel Coronavirus-infected pneumonia in Wuhan, China. JAMA. 2020;323(11):1061-9. https://doi.org/10.1001/jama.2020.1585

41. Wang $M$, Cao R, Zhang L, et al. Remdesivir and chloroquine effectively inhibit the recently emerged novel coronavirus (2019-nCoV) in vitro. Cell Res. 2020;30(3):269-71. https://doi.org/10.1038/s41422-020-0282-0

42. WHO Director-General's opening remarks at the media briefing on COVID-19 - 11 March 2020, World Health Organization (WHO), https://www.who.int/dg/speeches/detail/ who-director-general-s-opening-remarks-atthe-media-briefing-on-covid-19---11-march2020, (erişim tarihi: 28.04.2020)

43. WHO Timeline - COVID-19, World Health Organization (WHO), https://www.who.int/ news-room/detail/27-04-2020-who-timeline--covid-19, (erişim tarihi: 28.04.2020)

44. Wu F, Zhao S, Yu B, et al. A new coronavirus associated with human respiratory disease in China. Nature. 2020;579(7798):265-9. https://doi.org/10.1038/s41586-020-2008-3

45. Wu Z, McGoogan JM. Characteristics of and important lessons from the Coronavirus Disease 2019 (COVID-19) outbreak in China. JAMA. 2020;323(13):1239-42. https://doi.org/10.1001/jama.2020.2648

46. Yavuz SŞ, Ünal S. Antiviral treatment of COVID19. Turk J Med Sci. 2020;50(SI-1):611-9. https://doi.org/10.3906/sag-2004-145

47. Yeni Koronavirüs Hastalığı (COVID-19), T.C. Sağlık Bakanlığı, https://covid19bilgi.saglik.gov. tr/tr, (erişim tarihi: 30.04.2020)

48. Zhou P, Yang X Lou, Wang XG, et al. A pneumonia outbreak associated with a new coronavirus of probable bat origin. Nature. 2020;579(7798): 270-3. https://doi.org/10.1038/s41586-020-2012-7

49. Zhu $N$, Zhang $D$, Wang $W$, et al. A novel coronavirus from patients with pneumonia in China, 2019. N Engl J Med. 2020;382(8):72733.

https://doi.org/10.1056/NEJMoa2001017 